\title{
Climate, snow, and soil moisture data set for the Tuolumne and Merced river watersheds, California, USA
}

\author{
James W. Roche ${ }^{1,2}$, Robert Rice ${ }^{3}$, Xiande Meng ${ }^{3}$, Daniel R. Cayan ${ }^{4}$, Michael D. Dettinger ${ }^{5}$, \\ Douglas Alden ${ }^{4}$, Sarina C. Patel ${ }^{6}$, Megan A. Mason ${ }^{7}$, Martha H. Conklin ${ }^{3}$, and Roger C. Bales ${ }^{3}$ \\ ${ }^{1}$ Capitol Reef National Park, USDOI National Park Service, Torrey, UT 84775, USA \\ ${ }^{2}$ Environmental Systems Graduate Group, University of California, Merced, CA 95340, USA \\ ${ }^{3}$ Sierra Nevada Research Institute, University of California, Merced, Merced, CA 95340, USA \\ ${ }^{4}$ Climate, Atmospheric Sciences, and Physical Oceanography, Scripps Institution of Oceanography, \\ University of California, San Diego, La Jolla, CA 92093, USA \\ ${ }^{5}$ US Geological Survey, Carson City, NV 89701, USA \\ ${ }^{6}$ Earth and Planetary Science, University of California, Berkeley, CA 94720, USA \\ ${ }^{7}$ Department of Geosciences, Boise State University, Boise, ID 83725, USA
}

Correspondence: James W. Roche (jim_roche@nps.gov)

Received: 25 August 2018 - Discussion started: 10 September 2018

Revised: 11 December 2018 - Accepted: 6 January 2019 - Published: 17 January 2019

\begin{abstract}
We present hourly climate data to force land surface process models and assessments over the Merced and Tuolumne watersheds in the Sierra Nevada, California, for the water year 2010-2014 period. Climate data (38 stations) include temperature and humidity (23), precipitation (13), solar radiation (8), and wind speed and direction (8), spanning an elevation range of 333 to $2987 \mathrm{~m}$. Each data set contains raw data as obtained from the source (Level 0), data that are serially continuous with noise and nonphysical points removed (Level 1), and, where possible, data that are gap filled using linear interpolation or regression with a nearby station record (Level 2). All stations chosen for this data set were known or documented to be regularly maintained and components checked and calibrated during the period. Additional time-series data included are available snow water equivalent records from automated stations (8) and manual snow courses (22), as well as distributed snow depth and co-located soil moisture measurements (2-6) from four locations spanning the rain-snow transition zone in the center of the domain. Spatial data layers pertinent to snowpack modeling in this data set are basin polygons and $100 \mathrm{~m}$ resolution rasters of elevation, vegetation type, forest canopy cover, tree height, transmissivity, and extinction coefficient. All data are available from online data repositories (https://doi.org/10.6071/M3FH3D).
\end{abstract}

\section{Introduction}

The snowpack of the Sierra Nevada provides at least $40 \%$ of California's water supply (Roos, 1989) and has historically stored an amount of water equivalent to more than half of the available Sierra foothill reservoir storage (Bales et al., 2011a). Snowpack in the western US is highly vulnerable to climate warming, both in the recent past (Mote et al., 2005) and as expected in the coming decades, particularly at lower elevations (Fyfe et al., 2017; Miller et al., 2003; Young et al., 2009). Melting snow sustains soil moisture, streams, and other water sources well into the very dry and warm Mediterranean summer that typifies the area (e.g., Yarnell et al., 2010). Building our intuition about the sensitivity of the snowpack to current and future climates, as well as storm paths and timing, is critical to the future management of these areas. Snowpack water storage affects forest fire, forest health, invasive and threatened species, recreation, flooding, and local and downstream water supplies (Brekke et al., 2009; Dettinger, 2011; Ligare et al., 2012; Miller et al., 2009; Sala et al., 2000).

Soil moisture is the other major component of water storage in mountain ecosystems. As snowpack storage dimin- 


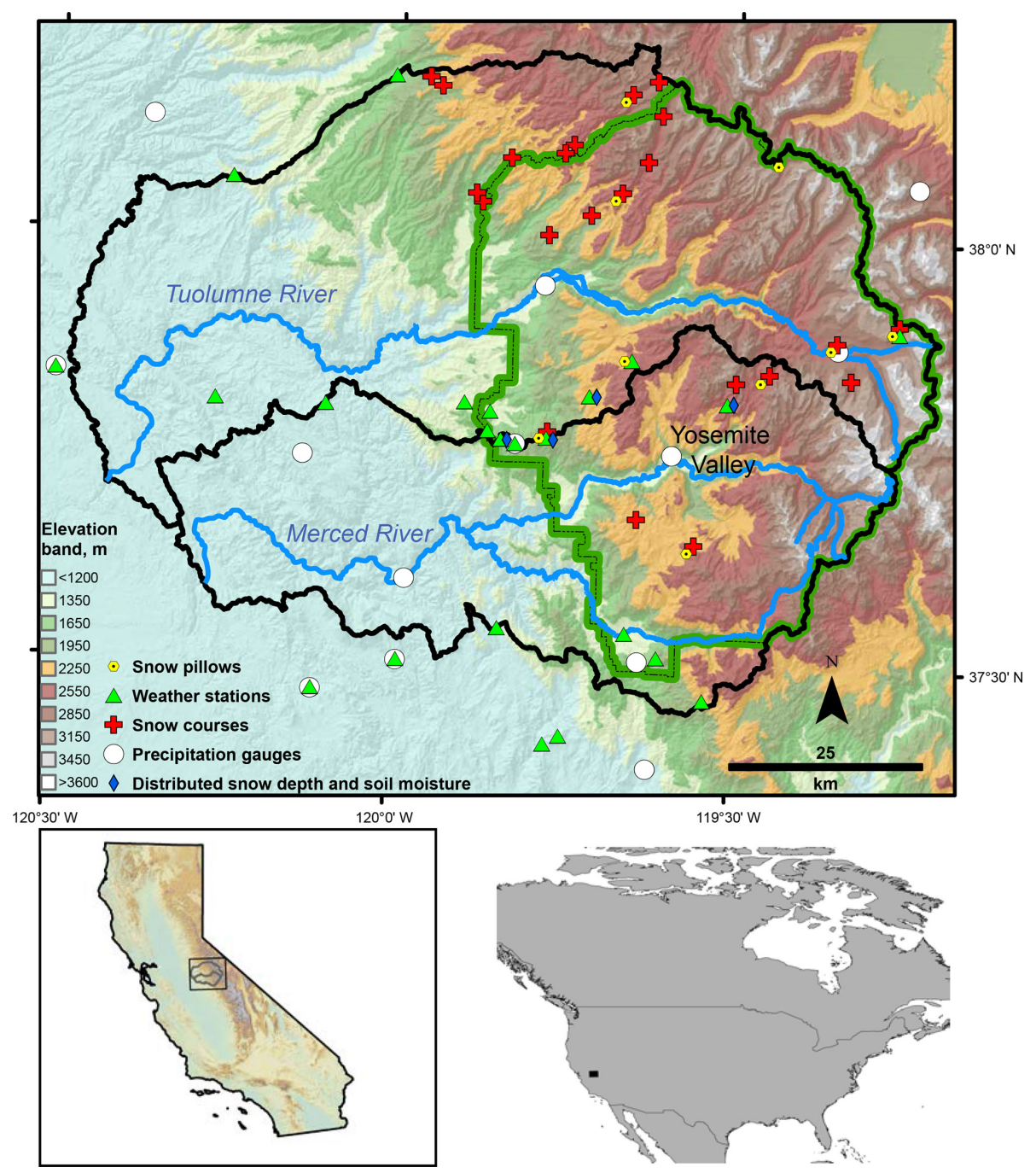

Figure 1. Hydrometeorological stations in and adjacent to the Merced and Tuolumne watersheds used in this data set. Co-located station types are offset for clarity. Yosemite National Park is demarked by the green boundary.

ishes, it will be essential to understand changes in soil moisture as it pertains to plant-available water, evapotranspiration, and, ultimately, forest health (e.g., Bales et al., 2018; Asner et al., 2016). The 2012-2016 California drought, including the 2015 "snow drought" (Harpold et al., 2017), and associated large-scale forest mortality highlight the importance of assessments that investigate the coupled changes in snowpack and soil moisture in mountain forests.

The purpose of this paper is to introduce climate, soil moisture, snow, and spatial data that may be used for hydrologic or land surface assessments and modeling in the Tuolumne and Merced watersheds in the Sierra Nevada of central California (Fig. 1; Tables 1, 2, 3). Hourly climate data and snow and soil moisture measurements were derived from stations within and immediately adjacent to the basins. Spatial data include basin polygon files and $100 \mathrm{~m}$ resolution raster files of elevation, and vegetation properties. We describe data sources, processing, limitations, and where to obtain the data. This data set complements stream and climate data compiled by Lundquist et al. (2016) for the upper parts of both watersheds as a part of the Yosemite Hydroclimate Network as well as meteorological and lidar-derived snow depth data compiled for a related snow-modeling study by Hedrick et al. (2018).

\section{Area description}

The study basins are west-draining watersheds on the broad western slope of the Sierra Nevada and ultimately tributaries to the San Joaquin River. The climate is generally characterized by cool, wet winters and long, warm, dry summers. Winter storms derive from large synoptic systems from the northern Pacific and more focused and moisture-laden atmospheric rivers from further south in the Pacific. Indeed, the 
Table 1. Measurements, operator, and instrumentation at each site.

\begin{tabular}{|c|c|}
\hline Measurement & Operator/instruments 1 \\
\hline Air temperature & $\begin{array}{l}\text { RAWS (various }{ }^{2} \text { ) } \\
\text { SIO, UCM (in-house-calibrated thermistors) } \\
\text { CA-DWR (Vaisala HMP45A/H DUS, Dana Meadow; FTS THS-3, Mariposa Grove) }\end{array}$ \\
\hline Relative humidity & $\begin{array}{l}\text { RAWS (various }{ }^{2} \text { ) } \\
\text { SIO, UCM (Sensirion, SHT15DV) } \\
\text { CA-DWR (Vaisala HMP45A/H DUS, Dana Meadow; FTS THS-3, Mariposa Grove) }\end{array}$ \\
\hline Precipitation & $\begin{array}{l}\text { RAWS (tipping bucket (typical); various }{ }^{2} \text { ) } \\
\text { MID (weighing-type, ETI Instrument Systems; tipping bucket, Briceburg) } \\
\text { CRN (Geonor }{ }^{\mathrm{TM}} \text { ) } \\
\text { NRCS (storage with pressure transducer) } \\
\text { DWR (storage with pressure transducer) } \\
\text { PGE (weighing-type, ETI Instrument Systems) } \\
\text { HHWP (Geonor }{ }^{\mathrm{TM}} \text { ) }\end{array}$ \\
\hline Solar radiation & $\begin{array}{l}\text { RAWS (Pyranometer, LICor 441A (typical) }{ }^{2} \text { ) } \\
\text { CA-DWR (LICor 441A) }\end{array}$ \\
\hline Wind speed/direction & $\begin{array}{l}\text { RAWS (various }^{2} \text { ) } \\
\text { CA-DWR (Vaisala 425A Ultrasonic) } \\
\text { UCM (3D sonic anemometer) }\end{array}$ \\
\hline Snow depth & Judd ultrasonic depth sensor \\
\hline Soil moisture & Decagon Devices, 5TE \\
\hline $\begin{array}{l}\text { Operator abbreviations are } \\
\text { Management; SIO - Scripps I } \\
\text { Resources; MID - Merced Irr } \\
\text { Pacific Gas and Electric; NOA } \\
\text { tttps://famit.nwcg.gov/applica }\end{array}$ & $\begin{array}{l}\text { en as follows: RAWS - Interagency Fire Remote Access Weather Station network managed by the Bureau of La } \\
\text { itution of Oceanography; UCM - University of California Merced; CA-DWR - California Department of Wate } \\
\text { tion District; HHWP - Hetch Hetchy Water and Power; NRCS - Natural Resource Conservation Service; PGE } \\
\text { - National Oceanic and Atmospheric Administration Climate Reference Network. }{ }^{2} \text { See RAWS (various; see } \\
\text { ns/RAWS, last access: } 14 \text { January 2019) for a description of instrument types. }\end{array}$ \\
\hline
\end{tabular}

latter may produce $20 \%-50 \%$ of annual precipitation for the area, and just a few storms may determine the difference between above-average water years and drought (Dettinger, 2011). Within the seasonal snow zone above $1800 \mathrm{~m}$ elevation, much of the landscape consists of broad interfluves between deep river canyons on the Merced and Tuolumne rivers, the area of Yosemite National Park. Most snowmelt runoff is generated between 2100 and 3000 m elevation, with up to $40 \%$ of runoff originating from elevations greater than $3000 \mathrm{~m}$, which is above existing measurements (Rice et al., 2011). Nearly $60 \%$ of the snowpack zone lies between the elevations of 2000 and $3000 \mathrm{~m}$ (Rice et al., 2011), and small changes in temperature during storms can result in large changes in runoff due to shifts in precipitation phase. This is illustrated in Fig. 2, which shows that wet-season winter temperatures in this zone hover close to $0^{\circ} \mathrm{C}$ in representative wet and dry years in the data set.

Dominant vegetation ranges from moisture-limited grasslands and oak woodlands below $1000 \mathrm{~m}$ elevation through ponderosa, mixed conifer (sugar pine, incense cedar, Jeffrey pine, and white fir), and red fir forests, to energylimited western white and lodgepole pine forests at and above $2500 \mathrm{~m}$ (Fites-Kaufman et al., 2007; Keeler-Wolf et al., 2012). Some of the largest and most productive forests in the world are located in the 1500-2000 m elevation range where there is neither moisture nor energy limitation (Kelly and Goulden, 2016; Matchett et al., 2015). Here, the mean winter temperature is a few degrees above freezing and precipitation averages $1100-1200 \mathrm{~mm} \mathrm{yr}^{-1}$ (PRISM Climate Group, 2012).

Like all major river basins in California, the Tuolumne and Merced are vitally important water sources to the economy of the region. The watersheds provide water for a large agricultural region of the Central Valley between Merced in the south and Modesto in the north, fed primarily by Lake McClure on the Merced and Lake Don Pedro on the Tuolumne River. Further upstream of the Tuolumne River, the Hetch Hetchy water system supplies water to 2.6 million San Francisco and other Bay Area residents.

\section{Climate data}

The original intent of assembling this data set was to force the snow energy- and mass-balance model iSnobal (Marks et al., 1999) at an hourly time step. The data represent the required parameters to drive the model: incoming solar radi- 


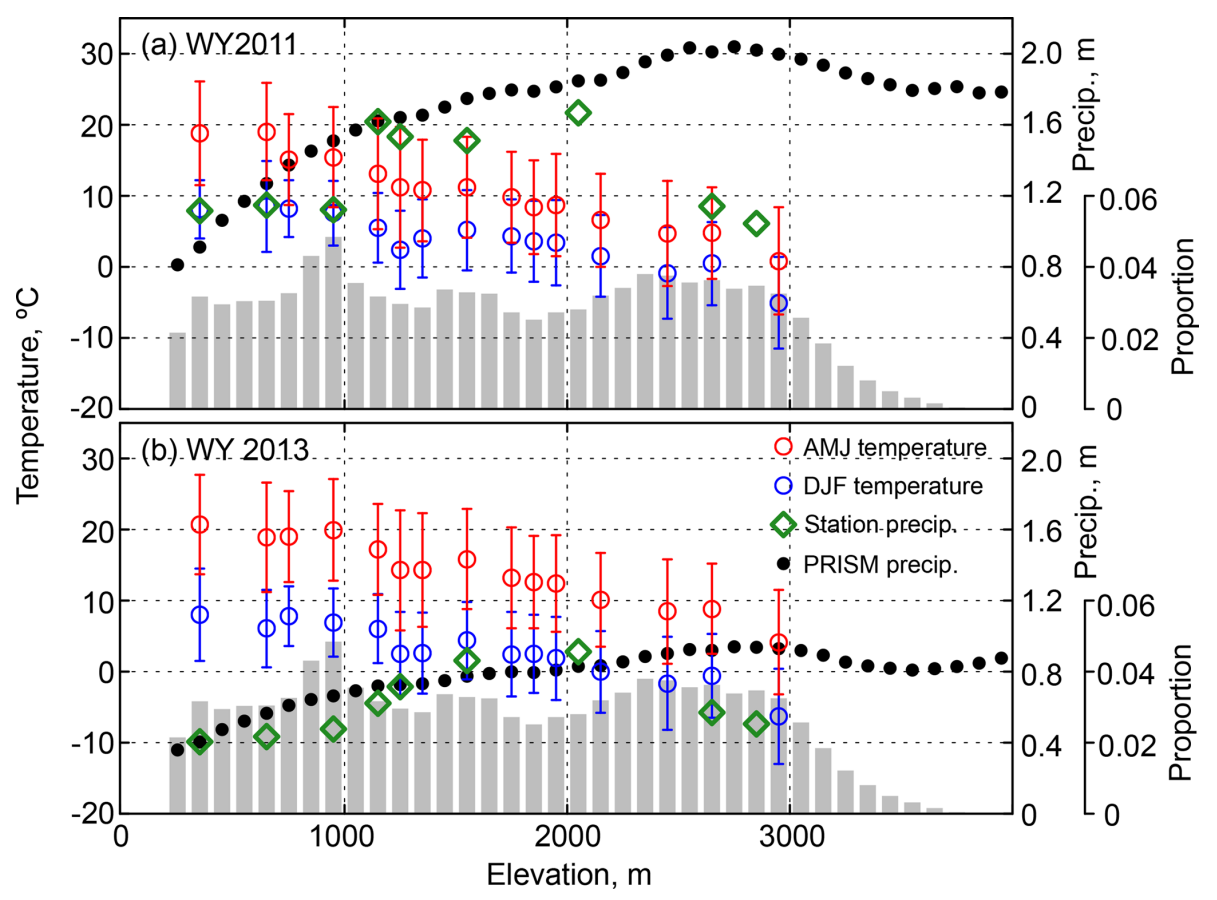

Figure 2. Elevation transects of temperature and precipitation in (a) wet and cold water year 2011, and (b) dry and warm 2013. Temperatures are 3-month means and standard deviations during the main snowpack accumulation period (December-February) and the main snowmelt season (April-June). Precipitation and temperature station data were averaged by $100 \mathrm{~m}$ elevation band. The shaded area is the proportional basin area in each $100 \mathrm{~m}$ elevation band.

ation, temperature, relative humidity, wind speed and direction, and precipitation. That modeling effort (Roche et al., 2018a) employed a subset of this data archive, which is described in succeeding sections (bold attributes in Table 2). Data were obtained from the California Data Exchange Center (CDEC) for California Department of Water Resources stations, Western Regional Climate Center for Fire Remote Access Weather Station (RAWS) network stations, and the Scripps Institution of Oceanography (SIO), which operates a transect of stations across the Sierra through the middle of the study domain. All raw data (Level 0) were processed to be serially continuous and to remove noise and nonphysical data (Level 1) and gap filled where possible using linear interpolation and regression with nearby stations (Level 2). Very few stations adequately measured all parameters and several stations have extensive periods with no data that precluded gap filling. As is typical in large mountain basins, instrumentation distribution is not uniform, often located where it is convenient to service, and heavily weighted to the lower elevations. More than two-thirds of the stations are below $2000 \mathrm{~m}$ elevation and no stations are located above $3000 \mathrm{~m}$ (Figs. 1, 2). Above $1800 \mathrm{~m}$, where seasonal snowpack occurs, there are three precipitation measurement stations, two of which are rain-shadow affected (Fig. 1). For this paper we have added the additional meteorological station and soil moisture data available in the same area, which provides a more complete hydrologic data set.

\subsection{Temperature and humidity}

Paired temperature $\left({ }^{\circ} \mathrm{C}\right)$ and relative humidity $\left(\mathrm{KPa} \mathrm{KPa}^{-1}\right)$ used for snow modeling were measured at 23 stations in this data set. Stations were chosen for modeling given known maintenance records at each site that assured minimal drift and accurate subsequent calculation of dew point and vapor pressure. Figure 3 illustrates dew-point and air temperature variability as recorded at Crane Flat Lookout over a 2-week period in late 2012 and early 2013. Also shown is the dew-point lapse rate (using the methods of Marks et al., 1999) derived from these 23 stations, which averaged -0.0055 and $-0.0065^{\circ} \mathrm{C} \mathrm{m}^{-1}$ during and between precipitation events. Temperature gradient varied from -0.0075 to $-0.0044^{\circ} \mathrm{C} \mathrm{m}^{-1}$ during wet periods and -0.0079 to $-0.0016^{\circ} \mathrm{C} \mathrm{m}^{-1}$ during dry periods. These data in combination with those of Lundquist et al. (2016) offer an interesting opportunity to further the temperature and dew-point lapse rate analyses of Lundquist and Cayan (2007) and Feld et al. (2013), respectively.

\subsection{Precipitation}

Hourly precipitation $(\mathrm{mm})$ was the most difficult parameter to obtain and process. The best quality records were those obtained from stations equipped with tipping-bucket gauges that were below $1000 \mathrm{~m}$ elevation where snow and ice are minimal. Weighing gauges in Yosemite Valley (1208 m), 
Table 2. Meteorological stations and data used to force model.

\begin{tabular}{|c|c|c|c|c|c|}
\hline Station name $^{1}$ & $\begin{array}{l}\text { Elev., } \\
\mathrm{m}\end{array}$ & $\begin{array}{r}\text { UTM easting }^{2}, \\
\mathrm{~m}\end{array}$ & $\begin{array}{r}\text { UTM northing }^{2}, \\
\mathrm{~m}\end{array}$ & Measurements used ${ }^{3}$ & Operator $^{4}$ \\
\hline Green Springs (GRN) & 311 & 4193067 & 191966 & $\mathbf{t}, \mathbf{r h}, \mathbf{p}, \mathrm{sr}, \mathrm{w}$ & RAWS \\
\hline Stanislaus Powerhouse (SPW) & 333 & 4225930 & 204880 & $\mathbf{p}$ & PGE \\
\hline Cathey's Valley (CVR) & 366 & 4151342 & 224905 & $\mathbf{t}, \mathbf{r h}, \mathbf{p}$ & RAWS \\
\hline Briceburg $(\mathrm{MBB})^{5}$ & 670 & 4153062 & 238501 & $\mathbf{p}$ & MID \\
\hline Mariposa (MRP) & 680 & 4154996 & 235967 & $\mathbf{t}, \mathbf{r h}, \mathbf{p}$ & RAWS \\
\hline Priest Reservoir (PRR-SIO) & 709 & 4189078 & 212647 & $\mathbf{t}, \mathbf{r h}$ & $\mathrm{SIO}$ \\
\hline Metcalf Gap (MCF) & 938 & 4143892 & 255011 & $\mathbf{t}, \mathbf{r h}, \mathrm{sr}, \mathrm{w}$ & RAWS \\
\hline Batterson (BTT) & 943 & 4140575 & 268301 & $\mathbf{p}$ & RAWS \\
\hline Dudley Ranch (DUC) & 1114 & 4151264 & 224864 & p & MID \\
\hline Smith Peak (SEW) & 1168 & 4188222 & 226980 & $\mathbf{s r}, \mathbf{w}, \mathrm{p}, \mathrm{t}, \mathrm{rh}$ & RAWS \\
\hline Smith Peak (SEW-SIO) & 1168 & 4188222 & 226980 & $\mathbf{t}, \mathbf{r h}$ & SIO \\
\hline Jerseydale (JSD) & 1189 & 4158967 & 249214 & t, rh, sr, w & RAWS \\
\hline Hetch Hetchy (HEM) & 1195 & 4203412 & 255489 & $\mathbf{p}$ & HHWP \\
\hline Wawona (WWN) & 1235 & 4158119 & 265654 & $\mathbf{t}, \mathbf{r h}, \mathbf{s r}$ & RAWS \\
\hline Yosemite Valley (YYV) & 1208 & 4181238 & 271843 & $\mathbf{p}$ & MID \\
\hline Miami Mountain (MIA) & 1321 & 4144912 & 257059 & $\mathbf{t}, \mathbf{r h}, \mathbf{s r}, \mathbf{w}$ & RAWS \\
\hline Sunset Inn (SUN-SIO) & 1371 & 4188288 & 245001 & $\mathbf{t}, \mathbf{r h}$ & $\mathrm{SIO}$ \\
\hline Hodgdon (HDG-SIO) & 1397 & 4187075 & 248304 & $\mathbf{t}, \mathbf{r h}$ & $\mathrm{SIO}$ \\
\hline Mount Elizabeth (MTE) & 1504 & 4217791 & 215134 & $\mathbf{t}, \mathbf{r h}, \mathbf{s r}, \mathbf{w}$ & RAWS \\
\hline Yosemite South Entrance (YOW) & 1511 & 4154480 & 267291 & $\mathbf{p}$ & MID \\
\hline Forty Mile (FTY-SIO) & 1723 & 4184565 & 247936 & $\mathbf{t}, \mathbf{r h}$ & $\mathrm{SIO}$ \\
\hline Pinecrest (PNW) & 1738 & 4230750 & 236322 & $\mathbf{t}, \mathbf{r h}, \mathbf{s r}, \mathbf{w}$ & RAWS \\
\hline Merced Grove (MEG-SIO) & 1810 & 4183446 & 249675 & $\mathbf{t}, \mathbf{r h}$ & $\mathrm{SIO}$ \\
\hline Mariposa Grove (MPG) & 1951 & 4154932 & 269754 & $\mathbf{t}, \mathbf{r h}, \mathrm{w}, \mathrm{sr}, \mathrm{p}$ & RAWS \\
\hline Crane Flat (CFL-CRN) & 2017 & 4182829 & 251510 & $\mathbf{p}$ & NOAA \\
\hline Crane Flat Lookout (CFL) & 2026 & 4182878 & 251530 & t, rh, sr, w, p & RAWS \\
\hline Gin Flat (GIN-SIO) & 2149 & 4183578 & 255577 & $\mathrm{t}, \mathbf{r h}$ & $\mathrm{SIO}$ \\
\hline Gin Flat (GIN) & 2149 & 4183578 & 255577 & $\mathrm{t}, \mathrm{rh}, \mathrm{w}, \mathrm{p}, \mathrm{sr}$ & CA-DWR \\
\hline Fresno Dome (FRS) & 2177 & 4149346 & 275698 & $\mathbf{t}, \mathbf{r h}, \mathbf{w}$ & $\mathrm{UCM}$ \\
\hline Smoky Jack (SMK-SIO) & 2182 & 4188935 & 261192 & $\mathbf{t}, \mathbf{r h}$ & SIO \\
\hline White Wolf (WHW) & 2408 & 4193540 & 266732 & $\mathbf{t}, \mathbf{r h}, \mathbf{s r}, \mathbf{w}$ & RAWS \\
\hline Ostrander Lake (STR) & 2499 & 4168599 & 274999 & $\mathrm{t}, \mathrm{rh}, \mathrm{w}$ & CA-DWR \\
\hline Horse Meadow (HRS) & 2560 & 4226695 & 266766 & $\mathrm{t}$ & CA-DWR \\
\hline Olmsted Quarry (OLM-SIO) & 2604 & 4187768 & 279089 & $\mathbf{t}, \mathbf{r h}$ & SIO \\
\hline Tuolumne Meadows (TUM) & 2622 & 4194700 & 293480 & $\mathbf{p}, \mathrm{t}, \mathrm{sr}$ & CA-DWR \\
\hline Virginia Lakes Ridge (VRG) & 2879 & 4215567 & 304085 & $\mathbf{p}$ & NRCS \\
\hline Dana Meadow (DAN) & 2988 & 4196683 & 301507 & $\mathbf{t}, \mathbf{r h}, \mathbf{s r}, \mathbf{w}$ & CA-DWR \\
\hline Tioga Pass Entry Station (TES) & 3041 & 4198329 & 301461 & $\mathrm{t}, \mathrm{rh}, \mathrm{w}$ & CA-DWR \\
\hline
\end{tabular}

\footnotetext{
1 Three-letter station name abbreviations are derived from conventions in the California Data Exchange Center database (http://cdec.water.ca.gov/, last access: 10 December 2018). Abbreviations ending with "-SIO" indicate stations operated by Scripps Institution of Oceanography that are not currently available through CDEC. CFL-CRN indicates the NOAA Climate Reference Network Station located near the Crane Flat Lookout. ${ }^{2}$ Geographic coordinates are in the Universal Transverse Mercator (UTM) projection, 1983 North American Datum, zone 11. ${ }^{3}$ Variable abbreviations: p, precipitation; rh, relative humidity; sr, solar radiation; t, air temperature; w, wind speed and direction. ${ }^{4}$ Operator abbreviations are given as follows: RAWS - Interagency Fire Remote Access Weather Station network managed by the Bureau of Land Management; SIO - Scripps Institution of Oceanography; UCM - University of California Merced; CA-DWR - California Department of Water Resources; MID - Merced Irrigation District; HHWP - Hetch Hetchy Water and Power; NRCS - Natural Resource Conservation Service; PGE - Pacific Gas and Electric; NOAA - National Oceanic and Atmospheric Administration Climate Reference Network. ${ }^{5}$ Actually located in the town of Mariposa, CA. Bold denotes parameters used in Roche et al., 2018a.
}

Yosemite South Entrance $(1511 \mathrm{~m})$, and Stanislaus Powerhouse $(333 \mathrm{~m})$, and Geonor ${ }^{\mathrm{TM}}$ gauges at Hetch Hetchy $(1195 \mathrm{~m})$ and the Crane Flat NOAA Climate Reference Network site $(2017 \mathrm{~m})$ were regularly maintained and appear to produce acceptable data. The only two high-elevation gauges were at Tuolumne Meadows (TUM) and Virginia Lakes Ridge (VLR) and both were accumulation-type gauges equipped with pressure transducers. The records from these gauges exhibit substantial diurnal expansion and contraction effects, adding uncertainty to the hourly records. To process these records, we first established a daily record by extracting the midnight value to minimize heating and cooling effects, differencing from the previous day and removing any negative values. For days with zero midnight values, all hourly 

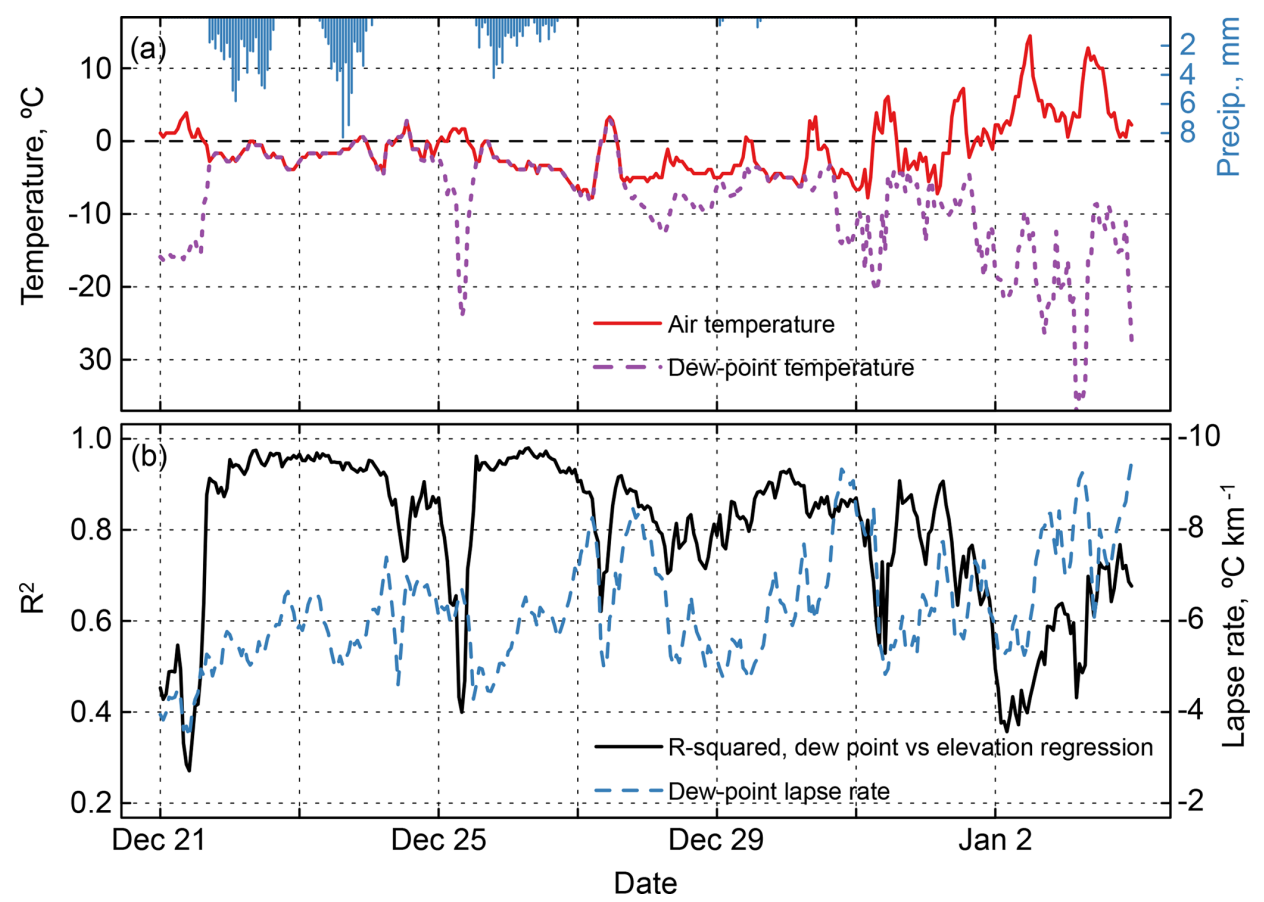

Figure 3. (a) Hourly time series of air temperature, dew-point temperature, and precipitation as recorded at Crane Flat Lookout RAWS and Crane Flat CRN stations for a 2-week period from 21 December 2012 through 3 January 2013. (b) Dew-point lapse rate and corresponding coefficient of determination for the same period for 23 stations with air temperature and relative humidity data (parameters shown in bold in Table 2).

values were set to zero. For days with nonzero accumulation, we first set all negative incremental values to zero and then multiplied positive increments by a constant so that the sum equalled the daily total. While these gauges are representative of their respective PRISM grid cells, they recorded $50 \%-60 \%$ of PRISM estimates in their respective elevation bands in water years 2011 and 2013 (Fig. 2) because they are in a rain shadow. These records may be used primarily to derive precipitation estimates elsewhere in the basin by scaling $800 \mathrm{~m}$ PRISM climate normals, as done by Lundquist et al. (2016), or as simple measures of precipitation timing rather than quantity.

\subsection{Wind speed and direction}

For snow modeling, we selected wind data from eight sites that were primarily located on open ridge lines in order to avoid the terrain- or forest-influenced winds. Terrain and vegetation effects could then be modeled using methods such as those of Winstral et al. (2009). Additional stations such as Tioga Pass Entrance Station (TES) and Gin Flat (GIN) provided a reference for forest wind speeds.

\subsection{Solar radiation}

All stations measured solar radiation using pyranometers that introduce substantial aspherical effects at dawn and dusk. Moreover, their calibration history was not known. Hence, the sites chosen for snow modeling were those with a largely complete record that spanned the domain and that exhibited minimal vegetation and terrain shading. As such, this record is best used as an estimate of cloudiness when combined with an independent estimate of incoming clear-sky solar radiation at each site (see Roche et al., 2018a for methods). Other stations in the data set exhibit substantially more terrain and vegetation shading influences. Records in the data set have not been corrected for shading.

\section{Snow and soil moisture data}

\subsection{Snow water equivalent}

We extracted all available monthly snow-course and daily snow-pillow data from CDEC for purposes of evaluating snow-modeling performance. Missing snow-course data were not gap filled, given substantial inter-site variability. Snow-pillow data were checked for serial completeness and outliers and gap filled using linear interpolation only. 
Table 3. Snow and soil moisture data sources.

\begin{tabular}{|c|c|c|c|c|}
\hline Station name ${ }^{1}$ & $\begin{array}{r}\text { Elev., } \\
\mathrm{m}\end{array}$ & $\begin{array}{r}\text { UTM northing }^{2}, \\
\mathrm{~m}\end{array}$ & $\begin{array}{r}\text { UTM easting }^{2}, \\
\mathrm{~m}\end{array}$ & Data type $^{3}$ \\
\hline Merced Grove (MEG-SIO) & 1810 & 4183446 & 249675 & distributed snow depth, soil moisture \\
\hline Bell Meadow (BEM) & 1981 & 4228435 & 242260 & monthly swe \\
\hline Beehive Meadow (BHV) & 1981 & 4208908 & 255883 & monthly swe \\
\hline Lower Kibbie (LKB) & 2042 & 4213387 & 247407 & monthly swe \\
\hline Lake Vernon (VNN) & 2042 & 4211186 & 261488 & monthly swe \\
\hline Upper Kibbie Ridge (UKR) & 2042 & 4214521 & 246651 & monthly swe \\
\hline Kerrick Ranch (KRC) & 2134 & 4229596 & 240718 & monthly swe \\
\hline \multirow[t]{2}{*}{ Gin Flat (GFL) } & 2134 & 4183363 & 255739 & monthly swe \\
\hline & 2134 & 4183578 & 255576 & daily swe \\
\hline Gin Flat (GIN-SIO) & 2134 & 4183350 & 255550 & distributed snow depth, soil moisture \\
\hline Peregoy Meadow (PGM) & 2134 & 4172111 & 268473 & monthly swe \\
\hline Smoky Jack (SMK-SIO) & 2182 & 4188935 & 261192 & distributed snow depth, soil moisture \\
\hline \multirow[t]{2}{*}{ Paradise Meadow (PDS) } & 2332 & 4214396 & 265710 & monthly swe \\
\hline & 2332 & 4214326 & 265612 & daily swe \\
\hline Huckleberry Lake (HCL) & 2377 & 4220692 & 259308 & monthly swe \\
\hline Spotted Fawn Lake (SPF) & 2377 & 4219616 & 258135 & monthly swe \\
\hline Sachse Spring (SAS) & 2408 & 4219048 & 251182 & monthly swe \\
\hline White Wolf (WHW) & 2408 & 4193540 & 266732 & daily swe \\
\hline Wilma Lake (WLW) & 2438 & 4218298 & 269071 & monthly swe \\
\hline \multirow[t]{2}{*}{ Tenaya Lake (TNY) } & 2484 & 4190665 & 284584 & monthly swe \\
\hline & 2484 & 4190534 & 284349 & daily swe \\
\hline \multirow[t]{2}{*}{ Ostrander Lake (STR) } & 2499 & 4168599 & 274999 & monthly swe \\
\hline & 2499 & 4168565 & 274701 & daily swe \\
\hline \multirow{2}{*}{ Horse Meadow (HRS) } & 2560 & 4226695 & 266766 & monthly swe \\
\hline & 2560 & 4227164 & 266940 & daily swe \\
\hline Olmsted Quarry (OLM-SIO) & 2604 & 4187768 & 279089 & distributed snow depth, soil moisture \\
\hline Tuolumne Meadow (TUM) & 2621 & 4194327 & 293307 & monthly swe \\
\hline Snow Flat (SNF) & 2652 & 4189558 & 280239 & monthly swe \\
\hline New Grace Meadow (NGM) & 2713 & 4225694 & 270684 & monthly swe \\
\hline Slide Canyon (SLI) & 2797 & 4218724 & 286737 & daily swe \\
\hline Bond Pass (BNP) & 2835 & 4228817 & 270246 & monthly swe \\
\hline Rafferty Meadow (RFM) & 2865 & 4190277 & 295406 & monthly swe \\
\hline \multirow[t]{2}{*}{ Dana Meadow (DAN) } & 2987 & 4196789 & 301552 & monthly swe \\
\hline & 2987 & 4196756 & 301486 & daily swe \\
\hline
\end{tabular}

\footnotetext{
${ }^{1}$ See footnote 1 in Table $1 .{ }^{2}$ See footnote 2 in Table $1 .{ }^{3}$ Data type explanations: monthly swe denotes manually measured snow courses, hourly swe indicates a snow-pillow site, and distributed snow depth indicates sites with four-six snow depth sensors distributed across an area of approximately $100 \mathrm{~m}^{2}$.
}

\subsection{Snow depth and soil moisture}

Snow-depth data were collected at four locations spanning the rain-snow transition zone along the Tioga Road at the Merced Grove (1810 m), Gin Flat (2149 m), Smoky Jack $(2182 \mathrm{~m})$, and Olmsted Quarry $(2604 \mathrm{~m})$. At each of the four locations, three-six snow depth sensor nodes were distributed over approximately $1-3$ ha according to canopy coverage (drip edge, under canopy, open canopy) as well as aspect (Rice and Bales, 2010; Kerkez et al., 2012). Each node was instrumented with a Judd snow depth sensor mounted $3 \mathrm{~m}$ above the ground surface. Snow data were filtered to remove unrealistic depths and checked for serial continuity (Level 1) and then gap filled using linear interpolation for periods of a few hours and regression with adjacent stations for larger gaps (Level 2).

Soil pits of $1 \mathrm{~m}$ depth were excavated at the drip edge, under canopy, and open canopy locations. At Merced Grove, Gin Flat, and Smoky Jack, the face of each pit was instrumented with soil moisture sensors at $10,30,60$, and $90 \mathrm{~cm}$ depths. Olmsted Quarry soil pits were instrumented at depths of 10,30 , and $60 \mathrm{~cm}$ due to the swallow soil. The soil moisture sensors were installed in undisturbed soil. The soil profiles were then back filled and hand compacted to maintain the original soil horizons and density as much as possible.

The soil moisture sensors installed for this study were the 5TE $(5.2 \mathrm{~cm}$ probe length), the successor to the family of Decagon ECH2O sensors studied by Kizito et al. (2008). That study evaluated the EC-5 and ECH2O-TE sensors for 
a wide range of soil solution salinity, temperature, and soil types. Their calibration measurements showed little probeprobe variability and demonstrated that a single calibration curve was sufficient for a range of mineral soils, suggesting there is no need for a soil-specific calibration (Bales et al., 2011b). To convert the Level 0 (raw data) to volumetric water content (VWC), the Topp equation (Topp et al., 1980) was applied: $\mathrm{VWC}=4.3 \times 10^{-6} \varepsilon^{3}-5.5 \times 10^{-4} \varepsilon^{2}+$ $2.92 \times 10^{-2} \varepsilon-5.3 \times 10^{-2}$, where $\varepsilon$ is the dialectic permittivity, which is the raw value reported by the Decagon 5 TE.

\section{Spatial data}

Spatial data included in this data set are basin polygons and raster files. All spatial data are in the Universal Transverse Mercator (UTM) zone 11 projection with the 1983 North American Datum. Basin polygons are in Earth Systems Research Institute (ESRI) ArcGIS shapefile format, while raster files are in ESRI ArcGIS ASCII grid format. Raster files include $100 \mathrm{~m}$ resolution elevation $(\mathrm{m})$, canopy cover (\%), generalized vegetation type, derived tree height $(\mathrm{m})$, derived canopy transmissivity (dimensionless), and canopy extinction coefficient $\left(\mathrm{m}^{-1}\right)$. The digital elevation model (DEM) was derived by resampling the $10 \mathrm{~m}$ U.S. Geological Survey National Elevation Dataset (NED) using bilinear interpolation. All other raster data sets were aligned with this DEM. The resulting raster contained 1296 columns and 1107 rows. Vegetation type, canopy cover, and tree basal area were derived from the U.S. Forest Service $30 \mathrm{~m}$ resolution California Region 5 Vegetation Maps (CALVEG, U.S. Forest Service, 2014) by determining the dominant overstory vegetation in each raster cell (Wildlife Habitat Relation (WHR) Lifeform), or spatially averaging canopy cover or basal area within each raster cell. We calculated tree height using basal area from the CALVEG data set and the allometric relation of Zhao et al. (2012). No attempt was made to compare our tree height grid with available lidar data. The WHR Lifeform designation was used to assign canopy transmissivity and extinction coefficients to each pixel based on the values from Link and Marks (1999). See Roche et al. (2018a) for more detail on the derivation of these layers. Basin polygons for the Merced and Tuolumne watersheds are in ESRI ArcGIS shapefile format.

\section{Data availability}

All data presented in this paper are available in the California Digital Library (https://doi.org/10.6071/M3FH3D, Roche et al., 2018b). Detailed metadata are associated with each file including contact information.

\section{Summary}

The data set assembled here represents the nature of data available in sparsely instrumented mountain basins coupled with the higher quality SIO Sierra transect and complimentary snow depth and soil moisture data set that has undergone quality control and gap filling. While it was used for one snow-modeling effort (Roche et al., 2018a), there are many opportunities to use the data for other applications, combining available raster data sets (PRISM, Basin Characterization Model, etc.) and testing the sensitivity of using more or fewer stations for estimating the attribute of interest. One outstanding use of the data set is an assessment of the temporal evolution of soil moisture with respect to snow accumulation and ablation across the rain-snow transition zone. Given the stark lack of measured short- and long-wave radiation in the watershed, other estimates of these attributes may be used to explore the sensitivity of model results. It is important for these kinds of data to be available for longer periods of time and in other watersheds in order to apply data-driven land surface modeling efforts that seek to minimize calibration in order to more robustly assess stressors on ecosystems.

Author contributions. RCB, RR, MDD, DRC, DA, and MHC designed the University of California Merced (UCM) and Scripps Institution of Oceanography (SIO) instrument networks. RR, DRC, MDD, DA, and JWR installed and maintained these same networks. DA, RR, XM, JWR, SCP, and MAM processed UCM, SIO, and external network station data. JWR prepared the manuscript with contributions from all authors.

Competing interests. The authors declare that they have no conflict of interest.

Special issue statement. This article is part of the special issue "Hydrometeorological data from mountain and alpine research catchments". It is not associated with a conference.

Acknowledgements. Support for this research was provided by the Yosemite Conservancy, the Merced Irrigation District through the California Integrated Regional Watershed Management Program (IRWMP), the Southern Sierra Critical Zone Observatory (grant number EAR-1331939), and the University of California Water Security and Sustainability Research Initiative. We acknowledge the contributions of Esther Canal, Anna Chovanes, and Haley Ramirez for their assistance with preparing the distributed snow depth data. Finally, peer review by Jessica Lundquist and Bruce McGurk greatly improved the manuscript and data set documentation.

Edited by: John Pomeroy

Reviewed by: Bruce McGurk and Jessica Lundquist 


\section{References}

Asner, G. P., Brodrick, P. G., Anderson, C. B., Vaughn, N., Knapp, D. E., and Martin, R. E.: Progressive forest canopy water loss during the 2012-2015 California drought, P. Natl. Acad. Sci. USA, 113, E249-55, https://doi.org/10.1073/pnas.1523397113, 2016.

Bales, R. C., Battles, J. J., Chen, Y., Conklin, M. H., Holst, E., O'Hara, K. L., Saksa, P., and Stewart, W.: Forests and Water in the Sierra Nevada: Sierra Nevada Watershed Ecosystem Enhancement Project Forests and Water in the Sierra Nevada, Sierra Nevada Watershed Ecosystem Enhancement Project, Sierra Nevada Research Institute Report, 11.1, 1-35, 2011a.

Bales, R. C., Hopmans, J. W., O'Geen, A. T., Meadows, M., Hartsough, P. C., Kirchner, P., Hunsaker, C. T., and Beaudette, D.: Soil Moisture Response to Snowmelt and Rainfall in a Sierra Nevada Mixed-Conifer Forest, Vadose Zone J., 10, 786-799, https://doi.org/10.2136/vzj2011.0001, 2011b.

Bales, R. C., Goulden, M. L., Hunsaker, C. T., Conklin, M. H., Hartsough, P. C., O'Geen, A. T., Hopmans, J. W., and Safeeq, M.: Mechanisms controlling the impact of multiyear drought on mountain hydrology, Sci. Rep.-UK, 8, 690, https://doi.org/10.1038/s41598-017-19007-0, 2018.

Brekke, L. D., Maurer, E. P., Anderson, J. D., Dettinger, M. D., Townsley, E. S., Harrison, A., and Pruitt, T.: Assessing reservoir operations risk under climate change, Water Resour. Res., 45, W04411, https://doi.org/10.1029/2008WR006941, 2009.

Dettinger, M.: Climate Change, Atmospheric Rivers, and Floods in California - A Multimodel Analysis of Storm Frequency and Magnitude Changes, J. Am. Water Resour. As., 47, 514-523, https://doi.org/10.1111/j.1752-1688.2011.00546.x, 2011.

Feld, S. I., Cristea, N. C., and Lundquist, J. D.: Representing atmospheric moisture content along mountain slopes: Examination using distributed sensors in the Sierra Nevada, California, Water Resour. Res., 49, 4424-4441, https://doi.org/10.1002/wrcr.20318, 2013.

Fites-Kaufman, J. A., Rundel, P., Stephenson, N., and Weixelman, D. A.: Montane and subalpine vegetation of the Sierra Nevada and Cascade ranges, in: Terrestrial Vegetation of California, edited by: Barbour, M., Berkeley, CA, University of California Press, 3rd Edn., 456-501, https://doi.org/10.1525/california/9780520249554.003.0017, 2007.

Fyfe, J. C., Derksen, C., Mudryk, L., Flato, G. M., Santer, B. D., Swart, N. C., Molotch, N. P., Zhang, X., Wan, H., Arora, V. K., Scinocca, J., and Jiao, Y.: Large near-term projected snowpack loss over the western United States, Nat. Commun., 8, 14996, https://doi.org/10.1038/ncomms14996, 2017.

Harpold, A. A., Dettinger, M., and Rajagopal, S.: Defining snow drought and why it matters, Eos T. Am. Geophys. Un., 98, https://doi.org/10.1029/2017EO068775, 2017.

Hedrick, A. R., Marks, D., Havens, S., Robertson, M., Johnson, M., Sandusky, M., Marshall, H. P., Kormos, P. R., Bormann, K. J., and Painter, T. H.: Direct insertion of NASA Airborne Snow Observatory-derived snow depth time-series into the iSnobal energy balance snow model, Water Resour. Res., 54, 8045-8063, https://doi.org/10.1029/2018WR023190, 2018.

Keeler-Wolf, T., Moore, P. E., Reyes, E. T., Menke, J. M., Johnson, D. N., and Karavidas, D. L.: Yosemite National Park vegeta- tion classification and mapping project report, Natural Resource Technical Report NPS/YOSE/NRTR-2012/598, 2012.

Kelly, A. E. and Goulden, M. L.: A montane Mediterranean climate supports year-round photosynthesis and high forest biomass, Tree Physiol., 36, 459-468, https://doi.org/10.1093/treephys/tpv131, 2016.

Kerkez, B., Glaser, S. D., Bales, R. C., and Meadows, M. W.: Design and performance of a wireless sensor network for catchmentscale snow and soil moisture measurements, Water Resour. Res., 48, https://doi.org/10.1029/2011WR011214, 2012.

Kizito, F., Campbell, C. S., Campbell, G. S., Cobos, D. R., Teare, B. L., Carter, B., and Hopmans, J. W.: Frequency, electrical conductivity, and temperature analysis of a low-cost capacitance soil moisture sensor, J. Hydrol., 352, 367-378, https://doi.org/10.1016/j.jhydrol.2008.01.021, 2008.

Ligare, S. T., Viers, J. H., Null, S. E., Rheinheimer, D. E., and Mount, J. F.: Non-Uniform Changes to Whitewater Recreation in California's Sierra Nevada from Regional Climate Warming, River Res. Appl., 28, 1299-1311, https://doi.org/10.1002/rra.1522, 2012.

Link, T. and Marks, D.: Distributed simulation of snowcover mass- and energy-balance in the boreal forest, Hydrol. Process., 13, 2439-2452, https://doi.org/10.1002/(SICI)10991085(199910)13:14/15<2439::AID-HYP866>3.0.CO;2-1, 1999.

Lundquist, J. D. and Cayan, D. R.: Surface temperature patterns in complex terrain: Daily variations and long-term change in the central Sierra Nevada, California, J. Geophys. Res.-Atmos., 112, D11124, https://doi.org/10.1029/2006JD007561, 2007.

Lundquist, J. D., Roche, J. W., Forrester, H., Moore, C., Keenan, E., Perry, G., Cristea, N., Lapo, K., McGurk, B., Cayan, D. R., and Dettinger, M. D.: Yosemite Hydroclimate Network: Distributed stream and atmospheric data for the Tuolumne River watershed and surroundings, Water Resour. Res., 52, 7478-7489, https://doi.org/10.1002/2016WR019261, 2016.

Marks, D., Domingo, J., Susong, D., Link, T., and Garen, D.: A spatially distributed energy balance snowmelt model for application in mountain basins, Hydrol. Process., 13, 1935-1959, https://doi.org/10.1002/(SICI)10991085(199909)13:12/13<1935::AID-HYP868>3.0.CO;2-C, 1999.

Matchett, J. R., Lutz, J. A., Tarnay, L. W., Smith, D. G., Becker, K. M. L., and Brooks, M. L.: Impacts of fire management on aboveground tree carbon stocks in Yosemite and Sequoia and Kings Canyon National Parks, Natural Resource Report NPS/SIEN/NRR - 2015/910, Fort Collins, Colorado, available at: https://irma.nps.gov/DataStore/DownloadFile/517374 (last access: 15 January 2019), 2015.

Miller, J. D., Safford, H. D., Crimmins, M., and Thode, A. E.: Quantitative Evidence for Increasing Forest Fire Severity in the Sierra Nevada and Southern Cascade Mountains, California and Nevada, USA, Ecosystems, 12, 16-32, https://doi.org/10.1007/s10021-008-9201-9, 2009.

Miller, N. L., Bashford, K. E., and Strem, E.: Potential Impacts Of Climate Change On California Hydrology, J. Am. Water Resour. As., 39, 771-784, https://doi.org/10.1111/j.17521688.2003.tb04404.x, 2003.

Mote, P. M., Hamlet, A. F., Clark, M. P., and Lettenmaier, D. P.: Declining Mountain Snowpack in Western North America, B. Am. 
Meteorol. Soc., 86, 39-49, https://doi.org/10.1175/BAMS-86-139, 2005.

PRISM Climate Group: United States Average Annual Precipitation, 1981-2010, Oregon State University, 2012.

Rice, R. and Bales, R. C.: Embedded sensor network design for snow cover measurements around snow pillow and snow course sites in the Sierra Nevada of California, Water Resour. Res., 46, W03537, https://doi.org/10.1029/2008WR007318, 2010.

Rice, R., Bales, R. C., Painter, T. H., and Dozier, J.: Snow water equivalent along elevation gradients in the Merced and Tuolumne River basins of the Sierra Nevada, Water Resour. Res., 47, W08515, https://doi.org/10.1029/2010WR009278, 2011.

Roche, J. W., Bales, R. C., Rice, R., and Marks, D. G.: Management Implications of Snowpack Sensitivity to Temperature and Atmospheric Moisture Changes in Yosemite National Park, CA, J. Am. Water Resour. As., 54, 724-741, https://doi.org/10.1111/17521688.12647, 2018a.

Roche, J. W., Rice, R., Meng, X., Cayan, D. R., Dettinger, M. D., Alden, D., Patel, S. C., Mason, M. A., Conklin, M. H., and Bales, R. C.: Climate, snow, and soil moisture data set for the Tuolumne and Merced River watersheds, California, USA, v5, UC Merced Dash, Dataset, https://doi.org/10.6071/M3FH3D, 2018b.

Roos, M.: Possible Climate Change And Its Impact On Water Supply In California, Proceedings Oceans, 1, 247-249, https://doi.org/10.1109/OCEANS.1989.592877, 1989.

Sala, O. E., Chapin III, F. S., Armesto, J. J., Berlow, E., Bloomfield, J., Dirzo, R., Huber-Sanwald, E., Huenneke, L. F., Jackson, R. B., Kinzig, A., Leemans, R., Lodge, D. M., Mooney, H. A., Oesterheld, M., Poff, N. L., Sykes, M. T., Walker, B. H., Walker, M., and Wall, D. H.: Global Biodiversity Scenarios for the Year 2100, Science, 287, 1770-1774, https://doi.org/10.1126/science.287.5459.1770, 2000.
Topp, G. C., David, J. L., and Annan, A. P.: Electromagnetic Determination of Soil Water Content: Measurement in Coaxial Transmission Lines, Water Resour. Res., 16, 574-582, https://doi.org/10.1029/WR016i003p00574, 1980.

U.S. Forest Service: Existing Vegetation - CALVEG, ESRI personal geodatabase, available at: https://www.fs.usda. gov/detail/r5/landmanagement/resourcemanagement/?cid= stelprdb5347192 (last access: 15 January 2019), 2014.

Winstral, A., Marks, D., and Gurney, R.: An Efficient Method for Distributing Wind Speeds over Heterogeneous Terrain, Hydrol. Process., 23, 2526-2535, https://doi.org/10.1002/hyp.7141, 2009.

Yarnell, S. M., Viers, J. H., and Mount, J. F.: Ecology and Management of the Spring Snowmelt Recession, BioScience, 60, 114127, https://doi.org/10.1525/bio.2010.60.2.6, 2010.

Young, C. A., Escobar-Arias, M. I., Fernandes, M., Joyce, B., Kiparsky, M., Mount, J. F., Mehta, V. K., Purkey, D., Viers, J. H., and Yates, D.: Modeling the Hydrology of Climate Change in California's Sierra Nevada for Subwatershed Scale Adaptation, J. Am. Water Resour. As., 45, 1409-1423, https://doi.org/10.1111/j.1752-1688.2009.00375.x, 2009.

Zhao, F., Guo, Q., and Kelly, M.: Allometric equation choice impacts lidar-based forest biomass estimates: A case study from the Sierra National Forest, CA, Agr. Forest Meteorol., 165, 6472, https://doi.org/10.1016/j.agrformet.2012.05.019, 2012. 